\title{
PRACTICE AND FUTURE OF ENERGY-EFFICIENT CONSTRUCTION IN THE REPUBLIC OF KAZAKHSTAN
}

\section{Rashid Sharipov}

Faculty of Engineering and Information Technology,

Kazakh-German University,

Almaty, Republic of Kazakhstan

\section{Olga Kudrevich}

Center for Technical Regulation and Standardization, Scientific and Production Republican

Unitary Enterprise

"Stroytehnorm",

Minsk, Republic of Belarus

\section{Dinara Tyulyubayeva}

Department of Science and Innovation, Kazakh-German

University,

Almaty, Republic of Kazakhstan

\section{Syrymgali Yerzhanov}

JSC Kazakh Research and

Design Institute of Construction

and Architecture,

Almaty, Republic of Kazakhstan

\section{Madina Shavdinova}

Faculty of Engineering and Information Technology,

Kazakh-German University, Almaty, Republic of Kazakhstan

Key words: energy saving and energy efficiency improvement, regulatory technical documents, secondary and renewable energy resources, heat consumption in buildings, design and construction of energy-efficient buildings, "green" economy, efficient ventilation systems

\section{Cite article:}

Rashid, S., Dinara, T., Madina, S., Olga, K., \& Syrymgali, Y. [2021]. Practice and future of energy-efficient construction in the republic of Kazakhstan. Journal of Applied Engineering Science, 19(1), 1 - 8. DOI: $10.5937 /$ jaes0-27404 


\title{
PRACTICE AND FUTURE OF ENERGY-EFFICIENT CONSTRUCTION IN THE REPUBLIC OF KAZAKHSTAN
}

\author{
Rashid Sharipov ${ }^{1}$, Dinara Tyulyubayeva ${ }^{2}$, Madina Shavdinova $^{1 *}$, Olga Kudrevich ${ }^{3}$, Syrymgali Yerzhanov \\ ${ }^{1}$ Faculty of Engineering and Information Technology, Kazakh-German University, Almaty, \\ Republic of Kazakhstan \\ ${ }^{2}$ Department of Science and Innovation, Kazakh-German University, Almaty, Republic of Kazakhstan \\ ${ }^{3}$ Center for Technical Regulation and Standardization, Scientific and Production Republican Unitary \\ Enterprise "Stroytehnorm", Minsk, Republic of Belarus \\ ${ }^{4} J S C$ Kazakh Research and Design Institute of Construction and Architecture, Almaty, \\ Republic of Kazakhstan
}

The article touches upon the problem of energy saving and increasing energy efficiency in the construction sector, which consumes a significant share of the country's energy resources. The issues of rational use of energy resources with the aspects of energy saving, energy efficiency and, correspondingly, environmental problems are becoming increasingly important, and their solution has become a strategic task for Kazakhstan. In order to give momentum to energy saving measures carried out in Kazakhstan, a number of laws, bylaws and programs related to the rational use of energy resources and energy efficiency have been adopted. To solve this problem, it is planned to carry out targeted measures to eliminate existing political, legislative, technical and information barriers. A regulatory technical base is being developed based on the most recent advances of construction science.

Key words: energy saving and energy efficiency improvement, regulatory technical documents, secondary and renewable energy resources, heat consumption in buildings, design and construction of energy-efficient buildings, "green" economy, efficient ventilation systems

\section{INTRODUCTION}

The development of a sustainable model of economic development in Kazakhstan is impossible without addressing issues related to energy saving and energy efficiency. Implementation of the policy of efficient and rational consumption of energy resources will result in restraining their consumption growth and reducing environmental impact $[14,16,17]$. Activities in this area will contribute to the modernization of the manufacturing industry, electric power industry, housing and utility sector as well as the transport sector through encouraging the application of new technologies and innovations.

The high-priority problem of the government in achieving the objectives for reducing the energy intensity of GDP is to establish an effective legislative framework to promote energy efficiency in energy-intensive sectors of the economy, as is proven in paper [1].

As part of legislative support of energy-saving and energy-efficiency measures, the Law of the Republic of Kazakhstan "On the support of the use of renewable energy sources" was adopted in 2009, the laws "On Energy Saving and Energy Efficiency Improvement", "On Introducing Amendments and Addenda to Some Legislative Acts of the Republic of Kazakhstan on energy saving and energy efficiency improvement" and their subsidiary laws were adopted in 2012. The "Program of modernization of housing and communal services until 2020" has been adopted. In 2013, the Government of Kazakhstan approved the Republican Program "Energy Saving
2020" and "Concept of Transition to Green Economy".

State, regional and sectoral energy saving programs, as well as energy saving programs developed at the level of separate legal entities, have been identified as the key instrument for the implementation of energy saving measures. To finance these programs, it is envisaged to use state budget funds, own and borrowed funds of enterprises and organizations, as well as other sources not inconsistent with the legislation [2, 3].

\section{MATERIALS AND METHODS}

One of the central points in a coherent transition to a green economy is the problem of energy saving and efficient use of energy $[15,18,19]$. This problem has not yet found its proper solution in the country's economic sectors, and currently, Kazakhstan is among the countries with the highest energy intensity of GDP.

In Kazakhstan, about $40-45 \%$ of all thermal energy produced in the country is spent for heating and high-temperature water supply, which makes energy saving in the operation of buildings one of the underlying themes of the development of the construction sector, according to review [2].

The need for energy-saving measures is justified on the grounds that during the years of Soviet power, in the republic a significant number of residential buildings were built, where energy losses do not meet modern requirements. According to studies conducted in 2010, in Kazakhstan, the heat energy consumption in buildings was 


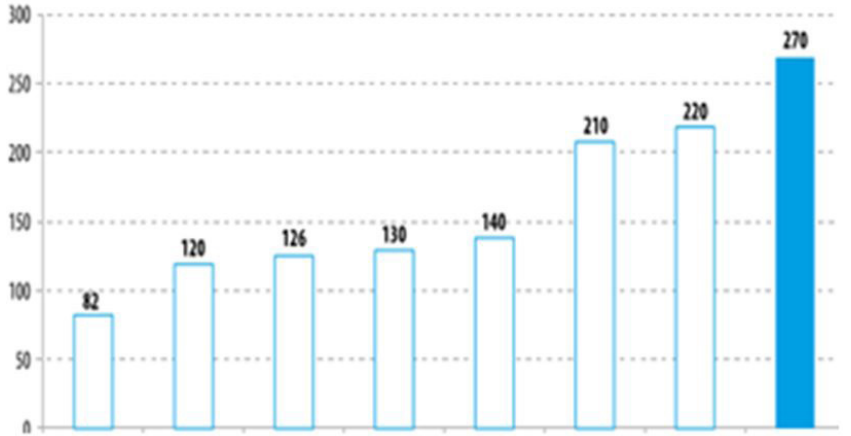

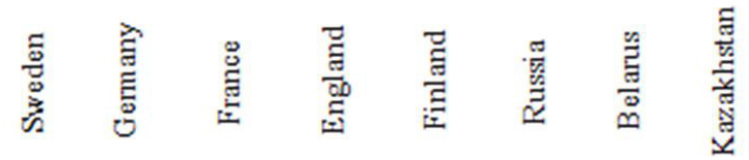

Figure 1: Comparison of individual heat consumption by buildings, $\mathrm{kWh} / \mathrm{m}^{2}$ per year

about $270 \mathrm{kWh} / \mathrm{m}^{2}$ per year, which is significantly higher than the European average (Figure 1).

However, significant differences in the climate of Kazakhstan and European countries must be noted. For example, the average temperature in Germany is $+1{ }^{\circ} \mathrm{C}$, while in Kazakhstan it is in the range from -19 to $-4{ }^{\circ} \mathrm{C}$, depending on the region, therefore, in Kazakhstan, heating of buildings requires a much larger amount of energy resources than in most European countries.

The main reasons of the irrational use of thermal energy are:

- Unregulated natural ventilation systems;

- Openings in enclosing structures;

- Disadvantages of architectural-planning and engineering solutions;

- Insufficient or poor insulation of exterior walls, coverings, basement ceilings and translucent fences;

- An extremely developed network of external heat pipelines in a pre-emergency condition;

- $\quad$ Outdated and mostly non-productive types of boiler equipment;

- Absence of the effective financial incentive mechanisms for power consumers in thermal energy saving;

- Very low use of non-conventional and secondary energy sources, etc.

- Mass energy-efficient housing construction in Kazakhstan will start once a number of problems are resolved. In particular, these problems are:

- Improvement of construction regulations and procedures for monitoring compliance with them;

- Promotion of technical assessment, standardization and certification of energy-efficient building materials produced in Kazakhstan;

- Providing enhanced information on opportunities of energy-efficient design and construction to manufacturers, designers and developers of buildings, pupils, students and the general public;
- Improving design and construction practices to increase energy efficiency in residential buildings, according to program [4].

Despite a number of strategic and regulatory and technical documents adopted in recent years regulating the energy efficiency improvement, the priority of energy efficiency in the technological chain of design, construction and operation of buildings is still low. There is no unequivocal answer to the question of why this is happening, since the final result of any construction always depends on a number of objective and subjective factors. According to experts, the situation largely depends on the problem associated with the insufficient number of mechanisms that allow the use of energy-saving technologies on a mandatory basis and insufficiently effective control of this problem.

\section{It should be noted that:}

- in the official documents approving the decision of the local executive body to issue a permit for the design and construction of a facility, as well as the commissioning of the facility, the building's energy efficiency class is not specified;

- $\quad$ with the adoption of the Law "On Energy Saving and Improving Energy Efficiency", mandatory examination of design and estimate documentation for energy saving and increasing energy efficiency for buildings with an annual consumption of more than 500 tsf (350 toe) per year was introduced into the design and construction practice.

- the energy performance certificate of the facility (provided for by the current building codes) is formed at the stage of design work by calculation and is submitted to the examination authorities. However, at the stage of commissioning the facility, the energy performance certificate of the building is not subject to analysis and adjustment based on the actual heat and power characteristics of the facility. After the construction of the facility, compliance with the energy efficiency class specified in the design and estimate documentation is not actually checked and is not subject to confirmation, which is one of the key barriers on the way to energy-efficient construction, thus it is necessary to strengthen the role of designer and technical supervision over the construction progress.

- quality control at the construction stage of the facility is provided by: the contractor, the customer (technical supervision), the design organization (designer supervision), the state (state architectural and construction supervision - SACI). All types of control are aimed at ensuring an appropriate level of quality during the construction process. However, at the stage of work of the acceptance committee for the commissioning of the facility, the result of the work of these instances is evaluated as a mere formality - depending on the presence or absence of documents (permits, approvals, executive documenta- 


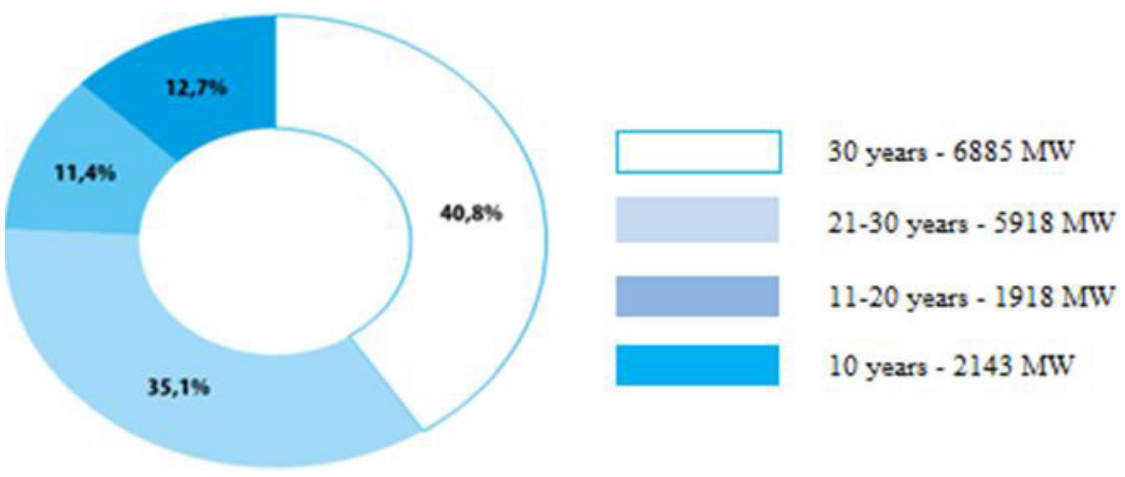

Figure 2: Service life of CHP plants

tion). After the commissioning of the facility, it is the new owner of the facility that faces quality issues - as a rule, an individual (in the case of residential buildings), who, during the warranty period, as a matter of priority seeks to locally (within one apartment) resolve the issues of the revealed defects (for example, to additionally insulate or replace low-quality windows, etc.).

It should also be noted that construction customers are often misled about the significant cost of energy-efficient construction. As the calculations of the implemented pilot projects in Kazakhstan show (including UNDP/GEF projects), the increase in the cost of construction when using a complex of energy-efficient technologies and materials does not exceed $10 \%$ of the construction cost.

In accordance with the "Program on the modernization of housing and communal services for 2011-2020" in Kazakhstan, works were carried out on thermo-modernization of houses of earlier construction combined with renovation of the roof, repair of basements, replacement and renewal of engineering systems, and installation of metering devices. Funds for this purpose were not allocated directly from the State budget due to the private ownership of most housing facilities (97.6\%). In this connection, owners of apartments and premises were involved in funding the repair of houses.

The effect of these works would be higher if there were no such negative reasons like:

- Lack of qualified personnel;

- The choice of the cheapest reconstruction options;

- The impossibility to radically improve heating systems in Khruschev-era housing with the purpose of metering systems installation;

- Absence of the possibility to organize efficient ventilation systems.

As a result, the cost per unit of heating has been reduced by no more than $10-15 \%$.

District heat supply with the use of the combined heat and power generation at combined heat and power plants (CHP) in Kazakhstan was most intensively developed in the period 1941-1980 and became the dominant heat supply system in all cities and most urban-type settlements between 1960 and 1990. Most CHP plants are coal-fired, while boiler houses most often use fuel oil. As can be seen from Fig. 2, the service life of $41 \%$ of the involved CHP plants is 30 years or more, and $35 \%$ of them are in operation for 20-30 years.

The high share of CHP plants in the heating system of urban buildings is the main advantage of the heat power industry in Kazakhstan. However, the construction and maintenance of extended heat networks is a "bottleneck" in the use of cogeneration, which, unless the infrastructure condition is properly monitored, can have a negative effect. Every year, in central heating systems, a significant part of the pipelines of heating networks is repaired and replaced, but this is costly.

The total length of heat networks (in the two-pipe calculation) is more than 12 thousand $\mathrm{km}$, including about 2.5 thousand $\mathrm{km}$ of heat networks with large diameters $(400-1000 \mathrm{~mm})$. About $70 \%$ of the total length of heat transport systems is more than 20 years old with the standard service life of 25 years. Two steel underground pipelines in reinforced concrete crawlways are used in the constructions of existing heat networks. On industrial sites and in special conditions of urban development, above-ground pipe installation on low or high reinforced concrete supports is applied. In recent years, there have been positive trends in the use of channelless pipe installation technology with polyurethane foam pre-insulation. At present, the majority of heat networks have poor insulation and therefore significant leakages through worn fittings and gland seals which is the main cause of excessive thermal and heat carrier medium losses. It is impossible to obtain reliable information about thermal losses during thermal energy transportation because, in most cases, metering devices are absent between transmission and distribution networks. According to expert assessment of the total amount of losses, up to $20 \%$ of losses account for the transmission heat networks and up to $80 \%$ account for distribution networks.

Nowadays there are projects on development of rooftop boiler-houses in multi-storey buildings.

Advantages of roof-top boiler houses:

- low costs for construction and installation works;

- low specific fuel consumption for heat production 133-154 kgoe/Gcal;

- minimum heat loss during transportation $-1-2.5 \%$;

- fully automated operation mode; 
- $\quad$ remote monitoring of work and the ability to control using a remote panel;

- $\quad$ the minimum number of service personnel.

Disadvantages of roof-top boiler houses:

- high unit cost of equipment for the production of a unit of thermal energy in comparison with boiler houses;

- they are inferior to cogeneration plants in terms of fuel utilization factor;

- lack of service infrastructure.

Mass introduction of local boiler-houses can lead to significant imbalance on the $\mathrm{CHP}$ and discharging into the environment hot water and steam, which are by-products of electricity production, which will adversely affect the environment, as demonstrated in review [2].

The program of energy saving and energy efficiency improvement requires mandatory accounting, control and the possibility of regulation of indoor climate parameters. Installation of heat energy meters has provided an opportunity for equitable distribution of payment for energy consumption in buildings and has increased interest of residents in energy saving. At the same time, heat energy meters have increased interest of heat networks operators in the reduction of heat losses when delivering heat to consumers.

Installation of heat supply meters and regulators in residential buildings made it possible to classify buildings by the indicator of specific heat consumption for heating and ventilation.

However, in multi-storey buildings in Kazakhstan, built before 2000, due to the design features of heat distribution systems, it is almost impossible to install metering devices for heat consumption in each apartment which in its turn leads to the absence of real metering of heat consumption for each separate customer.

The use of modern ventilation systems, as well as recuperation systems, in both old and newly constructed buildings is not yet adequately addressed. Typical multi-storey residential buildings have natural ventilation systems, which are inefficient (especially in summer, when there are massive cases of ventilating jet inversion). The disadvantages of natural ventilation include the fact that it does not comply well with modern energy saving requirements. It is known that from 30 to $75 \%$ of heat is removed from rooms with ventilation air, and besides the quality of air in rooms deteriorates, as is proven in paper [5].

Transition to forced, combined extract-and-input systems of ventilation with the recovery of heat energy from the exhaust air along with other energy-saving measures will further reduce costs for heating and ventilation of buildings. Practical experience in designing these systems, described in paper [6] shows that when constructing new houses in the Republic of Belarus, it will allow for saving up to $90 \%$ of heat from ventilation exhausts in apartments or $45 \mathrm{~kW} \cdot \mathrm{h} / \mathrm{m}^{2}$ per year.
The design and construction of energy-efficient buildings in Kazakhstan will certainly take into account the practical experience available in other countries. For example, in the Republic of Belarus, when implementing the integrated program for the design, construction and renovation of energy-efficient residential buildings, problematic issues have been identified hindering the widespread introduction of new types of buildings. The problems were primarily related to the specifics of the tariff policy implemented in the country. The use of forced, combined extract-and-input systems of ventilation with the recovery of heat energy from the exhaust air requires higher electrical energy consumption which with the existing tariff ratio has not reduced the total cost of heating and ventilation of buildings with energy-efficient ventilation systems compared to conventional buildings. Although it is common knowledge that buildings with forced, combined extract-and-input systems of ventilation with the recovery of heat energy from the exhaust air have better air quality and they do not have draughts. At the same time, the noise level decreases by reducing the impact of street noise, because there is no need to open windows and small ventilating windows, according to work [6].

One of the priority areas is the use of secondary and renewable energy resources. According to expert estimates, the potential for renewable energy resources in Kazakhstan is very significant. The law provides for a number of measures to support the use of renewable energy sources including reservation and priority in the provision of land plots for the construction of facilities using renewable energy sources, the obligations of power transmitting organizations to purchase electricity generated with the use of renewable energy sources, and exemption of business entities which use renewable energy sources from payment for transporting electricity through the networks. The law also provides for support in connection of facilities using renewable energy sources to the networks of the energy transmitting organization, providing investment preferences for legal entities and natural persons engaged in the design, construction and operation of facilities with renewable energy sources in accordance with the legislation of the Republic of Kazakhstan on investments.

Currently, appliances using non-conventional and alternative energy sources such as heat pumps, solar collectors, wind generators and others still play a modest role in the country's construction industry. In the future, as mentioned above, the practical experience of other countries concerning the use of non-conventional and alternative energy sources should also be taken into account.

In Grodno (the Republic of Belarus), heat pumps were provided for heating the building. One of these pumps used low-potential energy of the gathering sewage collector, and the second one took energy from foundation piles of the building. The electric energy efficiency measured during the operation of the heat pumps was 3.4 , i.e. with a prime costs ratio of 2.5 each kilowatt-hour 
of electric energy delivered 1 kilowatt-hour of heat free of charge. However, with the ratio between prices for electric energy for the population and the heating tariff equal to 10, the use of the heat pumps, even though the costs of electric energy were partially compensated by the use of the photovoltaic array, became unprofitable. This is largely responsible for the disconnection of the heat pumps by residents and the further heat supply to the building from the heating networks, as described in papers $[6,7]$.

The use of building structures and materials that meet energy efficiency requirements in modern construction plays an important role. Although Kazakhstan currently produces heat-insulating materials, the production of many energy-saving structures and materials used in construction, in particular modern translucent structures, heat-reflecting glasses, photovoltaic panels, and ventilated facade systems, has not yet been well-organized in sufficient volumes for the country's needs.

\section{RESULTS AND DISCUSSION}

One of the important elements of implementation of the energy saving and energy efficiency improvement policy is the development of normative and technical documents (NTD). Adoption and implementation since 01.05.2006 of the CN RK (Construction Norms of the Republic of Kazakhstan) 2.04-21-2004 "Energy Consumption and Thermal Protection of Civil Buildings" initiated the development of a new generation of normative and technical documents on energy saving in the civil engineering complex in the Republic of Kazakhstan.

\section{The specified Construction Norms}

- Have established numerical values for the standardized energy efficiency indexes for buildings;

- Have provided the classification of new and existing buildings according to their energy efficiency;

- Have opened up the possibility to construct buildings with higher energy efficiency indexes than the normalized ones;

- Have made it possible to identify buildings in operation that must be urgently reconstructed from the viewpoint of energy efficiency;

- Have provided the rules for designing the thermal protection of buildings using both componentwise normalization and energy efficiency indexes;

- Have provided methods of control over compliance with the specified parameters of thermal protection and energy efficiency both during design and construction and further during operation of buildings (energy passports);

- Have limited the design of buildings with energy consumption exceeding the established specified parameters, according to papers [8, 9].

From 2010 to 2025, Kazakhstan is reforming the system of technical regulation of the construction industry, which includes such a component as a regulatory framework. During 2010-2014, a new regulatory framework for the construction industry was developed, which included a number of NTDs, which directly or indirectly address energy saving and energy efficiency issues:

- CN RK "Rules for design and operation of solar high-temperature water supply installations";

- $\quad$ CN RK "Thermal protection of buildings";

- $\quad$ CN RK "Thermal insulation of equipment and pipelines";

- $\quad$ CR RK "Design of thermal protection of buildings";

- $\quad$ CN RK and CR RK "Energy Saving Buildings";

- $\quad$ CR RK "Design of energy-efficient, environmentally-friendly cottage buildings using alternative energy sources";

- $\quad$ CN RK and CR RK "Construction Heat Engineering";

- $\quad$ CN RK and CR RK "Heating Networks";

- CR RK "Autonomous heat supply sources" and some others.

In 2017 the SNiP RK "Construction climatology" was revised where, taking into account modern climatic changes, the design temperatures were specified for the settlements of the country (these design temperatures have not been revised since the 60s of the last century). This, according to expert opinion, created prerequisites for increasing energy saving for heating of buildings, as is proven in paper [9].

The main objective formulated during the development of the system of normative documents in the field of designing and construction of energy-efficient buildings consisted in the realization of the energy saving potential in the civil engineering complex through improving the energy efficiency of new, renovated and operated buildings and their energy supply systems. This is one of the stages in improving the energy efficiency of buildings, reducing greenhouse gas emissions from energy supply of newly constructed and renovated housing stock, thus facilitating the solution of global environmental problems, as well as energy and environmental safety of the country.

The analysis of the new regulatory framework showed that the requirements of the Law of the Republic of Kazakhstan No. 541-TV of January 13, 2012 "On Energy Saving and Energy Efficiency Improvement" to a great extent are fundamentally consistent with the concept of standardization contained in the EU directive on the energy performance of buildings [10]. The requirements contained in the law can be formally met by the new regulatory documents within the scope of the EU directive.

The analysis also showed that a number of errors and inaccuracies could not be avoided while developing new standards. In particular, the concept of "energy efficiency of buildings" is replaced by estimation of annual heat consumption, but along with this, requirements for electric energy savings for the drives of pumps and ventilators, 
air conditioning systems and lighting are not imposed. The level of thermal protection of claddings and the basic indicators of heat consumption is standardized for each region in terms of the heating season degree-days. In reality, the duration and the average temperature of the heating season of a building, which determines the degree-days, depend largely on the average daily internal heat generation. It is proposed to define the total energy consumption of a building as an arithmetical sum of heat and electricity consumption, while the energy intensity of electrical energy production is 2.5-3 times higher than the one of thermal energy. The list of comments can be continued, but the general conclusion on these documents is that they need to be further developed and revised, according to paper [11]. The process of harmonization of the domestic energy efficiency concept with that of the European Union countries defined in "Directive 2010/31/EU on the energy performance of buildings" continues, which is largely free from these disadvantages. At the same time, of course, the domestic experience in developing regulatory documents, peculiarities of the state and development of domestic production and construction industry, economy, climatic and geographical features are taken into account.

Currently, a methodology for determining the energy efficiency of buildings and structures that meets modern requirements is being developed that is harmonized with EU requirements (taking into account energy consumption for heating, ventilation, high-temperature water supply, air conditioning and electric power supply).

The innovations will make it possible not only to take into account in detail the energy consumption for the operation of buildings but also to improve energy-saving indicators both during the design and during their operation. At the same time, in the presence of separate regulatory documents and standards for determining the energy consumption of buildings, which regulate the procedure for determining the energy performance of buildings and their assessment, the process of adaptation of a series of European standards for determining the energy performance of buildings and their energy efficiency indicators as national is going on, as well as national annexes to them are being developed, according to recommendations [12, 13].

Recommendations on possible technical solutions and measures to improve the energy efficiency of heat supply and hot water supply systems are being developed. When designing new and reconstructing existing residential buildings, during the complex reconstruction of residential areas, residential buildings can be presented as:

- energy-saving residential buildings with specific energy consumption at or slightly below the current standard;

- $\quad$ energy-active - with the presence of energy-active structural elements and equipment in the building;

- energy-efficient - with the presence of a complex of energy-saving technical systems and energy-ac- tive elements and equipment, contributing to a significant (up to $50 \%$ and more) reduction in specific energy consumption against the current standards.

In accordance with this classification, in order to select the priority areas of energy saving, the requirements for systems and measures for residential buildings under construction and reconstruction given in Table 1 are recommended.

Low-cost measures are usually fast-payback and effective. However, a significant reduction in energy costs cannot be achieved only with their help. The greatest effect is provided by the introduction of a set of measures with different payback periods.

\section{CONCLUSION}

To date, it should be recognized that in Kazakhstan the work on energy saving in construction is still not being carried out effectively enough because:

- many regional programs are inaccurate and nonobjective due to the lack of statistical data;

- the regulatory and technical base in the field of design and construction of energy-efficient buildings requires further improvement;

- $\quad$ procedures for monitoring compliance with regulatory requirements also require improvement;

- further improvement of methods for drawing up energy performance certificates of buildings and conducting energy audit is necessary;

- $\quad$ improvement of methods for assessing buildings in terms of energy efficiency is necessary;

- there is a critical shortage of qualified energy saving specialists.

There is no clear understanding for the time being that the solution to the problem of revolutionary reducing energy costs can only be comprehensive and systemic.

The comprehensiveness means energy saving

- At the stages of design, manufacturing, construction (installation), commissioning, operation, repair, renovation and conservation of the object (system);

- At the stages of energy production, transmission and consumption;

- For all types of energy resources in general (fuel, electricity and heat) because in some cases saving of one type of energy resource leads to overuse of another;

- With legislative support and organizational and technical control by the state.

The systematic approach consists in the study of processes from general but not momentary positions. In developed countries, a comprehensive ideology of energy saving has been developed, and it has been proved that improving a separate element will not radically reduce energy consumption. 
Table 1: The content of energy-saving measures used in the construction of new and reconstruction of existing residential buildings

\begin{tabular}{|c|c|c|c|c|}
\hline \multirow[b]{4}{*}{$\begin{array}{c}\text { Cost } \\
\text { level of } \\
\text { measures }\end{array}$} & \multirow[b]{4}{*}{ Measures } & \multicolumn{3}{|c|}{$\begin{array}{l}\text { Specific heat energy consumption, Wh/m²•HSDD } \\
\text { (in parentheses for buildings under reconstruction) }\end{array}$} \\
\hline & & Energy-saving & Energy-active & Energy-efficient \\
\hline & & $\begin{array}{c}60-10 \\
(70-20) \\
\end{array}$ & $\begin{array}{c}80-30 \\
(90-40) \\
\end{array}$ & $\begin{array}{c}40-20 \\
(60-40) \\
\end{array}$ \\
\hline & & $\begin{array}{c}\text { energy } \\
\text { consumption } \\
\text { of the building } \\
\text { is below the } \\
\text { standard }\end{array}$ & $\begin{array}{l}\text { the building has } \\
\text { energy-active } \\
\text { structures and } \\
\text { equipment }\end{array}$ & $\begin{array}{c}\text { the building project } \\
\text { contains energy-sav- } \\
\text { ing and energy-active } \\
\text { solutions, contributing } \\
\text { to a significant reduc- } \\
\text { tion in heat consump- } \\
\text { tion (up to } 50 \% \text { or } \\
\text { more) }\end{array}$ \\
\hline \multicolumn{5}{|c|}{ Energy-saving measures } \\
\hline \multirow{6}{*}{$\begin{array}{l}\text { Low } \\
\text { cost }\end{array}$} & $\begin{array}{l}\text { Rational orientation of the building with respect to the } \\
\text { cardinal directions (for new construction) }\end{array}$ & * & ** & $* * *$ \\
\hline & Individual heat consumption control & * & ** & $* * *$ \\
\hline & $\begin{array}{l}\text { Installation of pressure regulators in hot water and water } \\
\text { supply }\end{array}$ & * & ** & ** \\
\hline & $\begin{array}{l}\text { Installation of heat-reflecting screens for } \\
\text { radiators }\end{array}$ & * & ** & $* * *$ \\
\hline & Preventing hot watercooling in the circulation pipe & * & ** & $* * *$ \\
\hline & $\begin{array}{l}\text { Exhaust ventilation control depending } \\
\text { on the gravitational component }\end{array}$ & * & & *** \\
\hline \multirow{7}{*}{$\begin{array}{l}\text { Medium } \\
\text { cost }\end{array}$} & $\begin{array}{l}\text { Local automation with software control and heat } \\
\text { consumption accounting }\end{array}$ & * & ** & ** \\
\hline & $\begin{array}{l}\text { Providing organizational infiltration of outside } \\
\text { air in the inter-glass space of a double-glazed unit }\end{array}$ & * & ** & ** \\
\hline & Installation of heating systems with apartment distribution & * & ** & $* * *$ \\
\hline & $\begin{array}{l}\text { Building front regulation (in the absence of an individual } \\
\text { one) }\end{array}$ & ** & ** & * \\
\hline & Cold water pre-heating & * & * & ** \\
\hline & Apartment-level heat recovery from exhaust air & * & * & $* * *$ \\
\hline & Installation of two-piece sinks and flush cisterns & * & * & ** \\
\hline \multirow{10}{*}{$\begin{array}{l}\text { High } \\
\text { cost }\end{array}$} & $\begin{array}{c}\text { Bringing the thermal resistance of the walls to the required } \\
\text { values according to the standards }\end{array}$ & ** & * & $* * *$ \\
\hline & $\begin{array}{c}\text { Use of energy-saving windows with increased thermal } \\
\text { resistance (up to } 1 \mathrm{~m}^{2} \cdot{ }^{\circ} \mathrm{C} / \mathrm{W} \text { ) }\end{array}$ & * & ** & $* * *$ \\
\hline & Use of passive solar systems & * & * & ** \\
\hline & $\begin{array}{l}\text { Separation of fecal and utility water with heat recovery } \\
\text { from conditionally clean wastewater }\end{array}$ & * & ** & ** \\
\hline & Creation of radiant and floor heating systems & * & * & ** \\
\hline & Use of active solar systems & * & * & ** \\
\hline & $\begin{array}{l}\text { Use of heat-pump heat supply systems using } \\
\text { low-grade sources (including thermopiles) }\end{array}$ & * & * & ** \\
\hline & $\begin{array}{l}\text { Use of central heat recovery systems for } \\
\text { exhaust air }\end{array}$ & * & $* *$ & * \\
\hline & $\begin{array}{l}\text { Apartment metering of energy and water } \\
\text { consumption }\end{array}$ & * & $* *$ & $* * *$ \\
\hline & Installation of apartment heat generators & * & * & * \\
\hline
\end{tabular}


Efficient solution of the abovementioned problems will significantly increase the efficiency of activities on energy saving and energy efficiency in the construction industry of the Republic of Kazakhstan.

\section{REFERENCES}

1. Kudrevich, O. O. (2018). Energy efficiency as a tool for achieving sustainable development objectives. Proceedings of the IV International Scientific and Practical Conference "Technical Regulation of the Construction Industry in Modern Conditions", 17-21.

2. KAZENERGY Association. (2014). Review of the State Policy of the Republic of Kazakhstan in Energy Saving and Energy Efficiency. Brussels.

3. Office of the President of the Republic of Kazakhstan. (2012). Law of the Republic of Kazakhstan No. 541-IV "On Energy Saving and Energy Efficiency Improvement". https://policy.asiapacificenergy.org/ ru/node/135

4. United Nations Development Programme in Kazakhstan. Global Environment Facility. (2015). Why is it profitable to construct energy-efficient buildings? Astana.

5. Tabunshchikov, Yu. A., Malyavina, E. G., \& Dionov, S. N. (2015). Mechanical ventilation - a way to comfort and energy saving. Energy Conservation, 3, 5-9.

6. Danilevsky, L. N. (2020). Prospects and directions of development of energy-efficient construction in the Republic of Belarus. Energy Efficiency, Minsk.

7. Gorshkov, A. S., Vatin, N. I., Rymkevich, P. P., Mozhaysky, A. F., \& Kydrevich, O. O. (2018). Payback period of investments in energy saving. Magazine of Civil Engineering, 2(78), 65-75. doi: 10.18720/ MCE.78.5

8. United Nations Development Programme and Global Environment Facility "Energy-efficient design and construction of residential buildings". (2011). Assessment of energy efficiency, accounting and monitoring of energy consumption and greenhouse gas emissions in the residential buildings sector. Astana.

9. Sharipov, R. Zh., \& Sabitbek, I. R. (2018). Implementation of the development program of standard technical documents of the Republic of Kazakhstan on the assessment of energy efficiency of buildings. Bulletin of JSC "KazNIISA", 4(80).

10. Directive 2010/31/EU of the European Parliament and of the Council of 19 May 2010 on the energy performance of buildings. https://eur-lex.europa.eu/ legal-content/EN/TXT/?uri=CELEX\%3A32010L0031
11. Terekhova, I. A., Danilevsky, L. N., \& Terekhov, S. V. (2012). Main issues of designing of energy efficient buildings. Stroitelnaya Gazeta.

12. Danilevsky, L. N. (2013). Recommendations for elimination of a gap between the national standards of energy characteristics and the standards adopted in the EU countries, applied to the newly constructed buildings. Minsk.

13. Tarnagurskiy, A. V. (2016). Justification, recommendations and draft regulations for step-by-step implementation of the energy efficiency certification system for buildings. Minsk.

14. Van Chien, N. (2020). Energy consumption, income, trading openness, and environmental pollution: Testing environmental Kuznets curve hypothesis. Journal of Southwest Jiaotong University, 55(1). doi: 10.35741/issn.0258-2724.55.1.49

15. Ghani, L. A., Mahmood, N. Z., Muhammad, Z., Bahri, S., \& Saputra, J. (2019). The Energy Flow for Maize Production: an Application of Material Flow Analysis (MFA) and Giddens Structural Theory. Journal of Southwest Jiaotong University, 54(4). doi: 10.35741/ issn.0258-2724.54.4.7

16. Kuznetsova, E. L., \& Makarenko, A. V. (2019). Mathematical model of energy efficiency of mechatronic modules and power sources for prospective mobile objects. Periodico Tche Quimica, 16(32), 529-541.

17. Semin, A. N., Ponkratov, V. V., Levchenko, K. G., Pozdnyaev, A. S., Kuznetsov, N. V., \& Lenkova, O. V. (2019). Optimization model for the Russian electric power generation structure to reduce energy intensity of the economy. International Journal of Energy Economics and Policy, 9(3), 379-387. doi: 10.32479/ ijeep.7552

18. Fedotova, O., \& Tabekina, O. (2013). Analysis of the current state of Russian enterprises greening. Journal of Contemporary Economics Issues, 1. doi: 10.24194/11301

19. Tabekina, O., \& Fedotova, O. (2013). Features of the process of ecologization of Russian enterprises. Journal of Contemporary Economics Issues, 2. doi: $10.24194 / 21307$ 